INGURUAK [71] | 2021 | 101-125

http://dx.doi.org/10.18543/inguruak-71-2021-art06

\title{
Genero indarkeria eta etxebizitza ez seguruko emakumeen bizitegi bazterketaren intersekzioa SARS-CoV-2 koronabirus pandemiaren garaian
}

\author{
The intersection of gender-based violence and female housing exclusion \\ in insecure housing during the SARS-CoV-2 coronavirus pandemic
}

\author{
Aitor Alzaga Artola* \\ Universidad del País Vasco/Euskal Herriko Unibertsitatea (UPV/EHU)
}

\begin{abstract}
LABURPENA: Estatu Espainiarrean eta munduko beste zenbait herrialdetan 2020eko martxoan etxe itxialdia ezarri zen, genero indarkeria bizi duten emakumeentzat suposatzen zuen segurtasun falta kontuan izan gabe. Testuinguru hori kontuan hartuz, artikuluak koronabirus pandemiaren garaian genero indarkeria eta etxebizitza ez seguruan bizi diren emakumeen bizitegi bazterketaren intersekzioa lantzen duen ikerketa bat du oinarritzat. Ekoizpen Narratiben teknikaren bidez, genero indarkeria jasaten duten emakumeekin lan egiten duten Bilbo Handiko lau elkartek parte-hartu dute ikerketan, ikertzailearekin elkarlanean ahots ezberdinak batzen dituen narratibak eraikiz. Emaitza nagusiek adierazten dute etxe itxialdiak emakumeen genero indarkeria larriagotzeaz gain haien bizitegi egoeran eragin negatiboa izan duela. Narratiben Ekoizpenaren bidez bizitegi bazterkeriaren ikuspegi androzentrikoa gainditu da, definizio honen pean ikusezintasunean gelditzen diren errealitateetara hurbilduz.
\end{abstract}

Hitz gakoak: bizitegi bazterkeria, COVID-19, androzentrismoa, ekoizpen narratiboak, genero indarkeria.

ABSTRACT: In March 2020 Spain and many other countries around the world stablished lockdown, without considering the insecurity it meant for gender-based violence women. Considering this context, the paper is built on a study that addresses the intersection of gender-based violence and the housing exclusion of women living in insecure housing during the coronavirus pandemic. Through Narrative Productions technique there have participated four associations of Greater Bilbao that work with women who suffer gender violence, building narratives putting together different voices. The main findings indicate that lockdown has not only aggravated gender-based violence in women, but also negatively impacted on their living situation. Narrative Productions have overcome the androcentric vision of housing exclusion and have make possible an approach to realities that remained invisible under its definition.

Keywords: housing exclusion, COVID-19, androcentrism, narratives, gender violence.

\footnotetext{
*Harremanetan jartzeko/Correspondence to: Aitor Alzaga Artola. Universidad del País Vasco/Euskal Herriko Unibertsitatea (UPV/EHU) - aitoralzaga3@gmail. com - https://orcid.org/0000-

Nola aipatu/How to cite: Alzaga Artola, Aitor (2021). «Genero indarkeria eta etxebizitza ez seguruko emakumeen bizitegi bazterketaren intersekzioa SARS-CoV-2 koronabirus pandemiaren garaian"; Inguruak, 71, 101-125. (http://dx.doi.org/10.18543/inguruak-71-2021-art06).

Jasoa/Received: 2021 ekaina 12; Onartua/Final version: 2021 abendua 6.

ISSN 0214-7912 / (c) 2021 UPV/EHU
}

(c) (i) (\$) Lan hau Creative Commons Aitortu-EzKomertziala-LanEratorririk 4.0 Nazioartekoa lizentzia baten mende dago 


\section{SARRERA}

Ikerketa honek SARS-CoV-2 koronabirus pandemiaren itxialdi garaian etxebizitza ez seguruan genero indarkeria jasaten duten emakumeen bizitegi bazterkeria aztertu du. Alde horretatik, ikerketa honek bizitegi bazterkeria du aztergai eta genero indarkerian arreta jartzen du. Urteetan zehar bizitegi bazterkeriaren inguruko analisiak eta diseinaturiko politikak ikuspegi androzentriko batetik egin dira zeinetan gizonezkoari erdiguneko posizioa eskaintzen zaion. Bizitegi bazterkeria soilik kalean bizi diren pertsonen errealitate gisa definituz gero, emakumezkoen bizitegi bazterkeria ikusezina bilakatzen da. Hori dela eta, ikerketa honetan ulerkera androzentriko hori gainditzeko asmoarekin, etxebizitza ez seguruan zentratu naiz. Ikerketan parte hartu duten ahots ezberdinek azaldu didaten bezala, etxebizitza genero indarkeria jasaten duten emakumeentzat ez da espazio segurua, kartzela baizik.

Ikerketa hau beharrezko zein erabilgarria da bertan lantzen den gaiak gaurkotasun handia duelako. Honekin esan nahi dudana da ikerketa honetatik ateratako ekarpenak erabilgarriak izan daitezkeela egungo egoerarako. Ildo honetatik jarraituz, Martxoan ezarritako itxialdiak, esaterako, emakume ugari haien erasotzaileekin denbora gehiago igarotzera behartu zituen, haien tratu txarreko egoera biziagotuz. Espainiako Berdintasun Ministerioak eskaintzen dituen datuen arabera, 2020ko apirilean 2019koan baino \%61 dei gehiago egin ziren 016ra, hau da, Estatu mailan genero-indarkeriaren biktimei informazioa eta aholkularitza emateko doako telefonora. Horrez gain, kontuan izan behar dugu etxeko itxialdia, etxeratzeko agindua edo deseskalatzea bezalako neurriek etxebizitza abiapuntutzat izan dutela, azkenengo hau espazio segurua izango balitz bezala ulertuta.

Hau guztia kontuan hartuta, lanak duen interes politiko zein soziala ikusezinean dauden egoera eta errealitate horiek ikusgarri egitea da, bizitegi bazterkeriaren inguruan hartzen diren politika edo estrategia neurriek zein bideratutako baliabideek kontuan har ditzaten.

Ikerketaren behaketa-unitateari dagokionez, Bilbo Handian genero indarkeria jasaten duten emakumeekin lan egiten duten lau elkartetan jarri dut arreta. Hain zuzen ere, ikerketa honen helburu nagusia, aurretik aipatu bezala, etxebizitza ez seguruan genero indarkeria jasaten duten emakumeen errealitateak ikusgarri egitea denez, metodologia feministaz baliatu naiz. Honela, bizitegi bazterketaren ulerkera androzentrikoa gainditzeko asmoarekin, Ekoizpen Narratiboen teknika erabili dut akademiaz haratago dagoen ezagutza anitz, aberats eta ezberdina ezagutu ahal izateko. Horrez gain, teknika honek parte-hartzaileekin harreman estuagoa ahalbidetu dit, simetria-egoera batera hurbildu nahian.

Lanaren egiturari dagokionez, lehenik eta behin, ikerketa honetan izandako helburu orokorrak eta espezifikoak azalduko ditut. Gero bizitegi bazterketaren inguruko esparru teorikoan eta testuinguruan murgilduko gara. Ondoren, ekoizpen narratiboen ikuspegi teoriko-metodologikoaren egokitasunari, azterlan honetan duen aplikazio zehatzari eta beste gai metodologiko batzuei erantzungo zaie. Jarraian, narratiba horietatik ehundutako kontakizunen analisia egin da. Azkenik, ondorioak eta erabilitako bibliografia. 


\subsection{Helburuak}

Ikerketa hurrengo helburu orokorrek gidatu dute:

-SARS-CoV-2 koronabirus pandemiaren testuinguruan, genero indarkeria dela-eta, etxebizitza ez-seguruan bizi diren emakumeen egoeran sakondu, pandemiak egoera horretan izan duen eraginean arreta jarriz.

-Etxebizitza ez seguruan bizi diren emakumeen bizitegi bazterketa ikusgarri egin genero ikuspegia aplikatuz.

Helburu orokor horiek bete ahal izateko ezinbestekoak izan dira ikerketaren hurrengo helburu espezifikoak:

- Administrazio Publikoak genero indarkeriagatik bizitegi bazterkeria pairatzen duten emakumeei eskaintzen dizkieten baliabideek haien beharrak asetzen ote dituzten jakitea.

-SARS-CoV-2 koronabirus pandemiaren aurrean aplikaturiko neurriek etxebizitza ez-seguruetan bizi diren emakumeen bizitegi-egoeran izan dituzten ondorioak ezagutzea.

-SARS-CoV-2 koronabirus pandemiak etxebizitza ez-seguruetan bizi diren emakumeen genero indarkeria egoeran izandako eragina azaltzea.

- Genero indarkeriaren ondorioz etxebizitza ez seguruan bizi diren emakumeen ahalduntzerako estrategien funtzionamendua aztertzea.

\section{ETXEBIZITZAREN ERAIKUNTZA ANDROZENTRIKOA}

\subsection{Etxebizitzaren eskubidea}

Egungo gizarte mendebaldar kapitalistetan ukaezina da etxebizitzak gizakion bizitzaproiektuetan duen zentraltasuna. Bizitegi egiturak gizarte antolakuntzan betetzen dituen funtzioak direla-eta etxebizitza ezinbesteko elementua da edonor normaltasunez gizartean integratu ahal izateko (Hernández Pedreño, 2013). Beraz, etxebizitza lehen mailako gizarte behar gisa ulertu behar da: gizartearen nukleoan aurkitzen da eta ezinbesteko gizarte prozesuren garapenerako oinarria da, zeina blokeatu daitekeen bizitegi beharrak asetzen ez badira (Cortés, 1997). Etxebizitza duina funtsezkoa da bizirauteko eta bizitza seguru zein burujabe bat izateko, baina ezin da soilik sabaia bat izatera mugatu, Pisarello-k azaltzen duenez:

Etxebizitzaren eskubidea ezin da parekatu, zentzu murriztailean, sabai bat buruaren gainean edukitze hutsagatik sortzen den babeslekuarekin, edo merkatuan soilik ordain dezaketenen esku dagoen merkantziarekin. Aitzitik, edozein lekutan duintasun, segurtasun eta bakearekin bizitzeko eskubide gisa ulertu behar da. Honek esan nahi du bizigarritasun-eskubideen hurbilketa bermatzaile batek ez dituela soilik «etxebizitza» izeneko egitura baten adierazpen fisikoak onartu behar, baita prozedura eta segurtasun-alderdiak ere, aspektu ez materialak, azken batean, bizitzeko eskubideenak, zeinak azken finean, sabai bat izatearen probisioa bezain garrantzitsuak edo garrantzitsuagoak izan daitezken. (Pisarello, 2003:81) 
Pisarello-k aipatutakoaren harira, nazioarteko organismoetatik zehaztu da «etxebizitza duinaren» eskubideak hurrengoak barnebiltzen dituela: espazio segurua, habitagarria, argitasuna eta aireztapena duena, zerbitzuen erabilgarritasunarekin, osasunerako ezinbestekoak diren erraztasun zein azpiegiturak eskura izatea, higienea, erosotasuna eta nutrizioa, gastuak eskuragarriak eta eramangarriak izatea, ingurumen, gizarte eta kultura zentzua jarraituz egokiak diren lekuetan eraikia izana (Vicente; Rubio eta Martínez, 2013). Ikerketa honek etxebizitzaren baldintza material horietan zentratu ordez, segurtasun edo habitagarritasun egoeran jarriko du arreta indarkeria jasan duten emakumeen errealitatea kontuan izateko, Paglione-ren proposamenarekin bat eginez: «Esklusiboki segurtasun materialean jarritako arretak erabat baztertzen du etxeetan haien bikoteek eragindako abusuak jasaten dituzten emakumeen errealitatea, eta ez ditu kontuan hartzen emakume guztien etxebizitza-eskubide zein beharrak.» (Paglione, 2006:127)

\subsection{Etxebizitzaren eraikuntza mitifikatua}

Etxebizitzaren inguruan eraikitako mitoa lotuta dago espazioaren banaketa androzentrikoarekin. Espazioa, beraz, boterearekin lotu behar dugu eta onartu behar da ez dela neutrala (Cevedio, 2003:42). Industrializazio garaitik honaino etxebizitzak egunerokotasunerako beharrezkoa den segurtasuna eskaintzen duen babesleku gisa funtzionatzen duenaren ideia garatzen joan da. Etxebizitza espazio itxia da eta ulertzen da kanpoarekiko babesten gaituela, eguraldi txarra egitean aterpea ahalbidetuz eta ingurune sozialetik ere babestuz (Cortés, 1997).

Kontua da, etxebizitzaren deskribapen honek ez dituela aintzat hartzen espazio honen barnean ehuntzen diren botere harremanak, hau da, gatazka guztiz alde batean uzten du. Etxebizitza ulertzea babes eta segurtasunaren espazio gisa, non guztien arteko ulertzea, bakea eta kideen arteko maitasuna zein onarpena gauzatzen diren ideia mitifikatua da (Osuji eta Hirst, 2015). Batzuetan etxeko giroak bertan bizi diren emakumeen bizitzetan desorekak eragin ditzake. Adibidez, etxebizitza leku duten gatazkek emakumeek etxetik alde egitea ekar dezakete. Gatazka horiek edo indarkeria erasoek etxebizitzan izandako "segurtasun» sentsazioarekin amaitzen dute eta indarkeria hori pairatzen duten emakumeentzat espazio hori dagoeneko ez da habitagarria izango. Eraso horien ondorioz, emakumeek etxean egotearen sentsazioa galdu dezakete, dagoeneko ez dute haien «etxetzat» joko beraien bizilekua (Osuji eta Hirst, 2015):

Abusuak jasan dituen emakumeari sistematikoki segurtasuna, bakea eta duintasuna kentzen zaizkio. Jasaten duen indarkeriak etxeko giroa zapalkuntza, beldur eta umiliazio lekua bihurtzen du. Dagoeneko etxea ez da babes eta armonia lekua, baizik eta kartzela, eta gizonezko bikotea torturatzaile amorratua da. (Paglione, 2006:126)

Hain zuzen ere, publiko-pribatuaren arteko dikotomiak birproduzitu egiten du aipatutako ideia mitifikatua: etxebizitzaren eremu pribatua segurua da emakumeentzat eta es- 
pazio publikoari, berriz, beldurra izan behar diote (Col•lectiu Punt 6, 2019). Kontua da, familia gatazken eta kontraesanen haztegia dela: babesleku seguru gisa aurkezten zaigu eta, zentzu horretan, bizikideen behar psikologikoz beteta dago, baina, aldi berean, giza grina bortitzenak irudikatzen diren agertokia da (Osborne, 2009:108). Gainera, emakumeen aurkako indarkeria nagusiki espazio pribatuan gertatzen da eta askotan ezaguna den pertsona bat izaten da erasotzailea.

\section{BIZITEGI BAZTERKETA}

\subsection{ETHOS tipologia}

Bizitegi bazterketaren kontzeptuak nolabait ordura arte izandako pertzepzio indibidualizatzailea alderantzikatu egingo du, egituran garrantzia handiago jarriz (Agulles, 2019). Honela, 2005 urtean FEANTSA-k, Etxerik Gabeko Pertsonekin Lan egiten duten Estatu Erakundeen Europar Federazioak, ETHOS (European Typology of Homelessness and Housing Exclusion) deituriko tipologia sortu zuen. Sailkapenak lau kontzeptu-kategoria (etxerik gabe, etxebizitzarik gabe, etxebizitza ez-segurua eta etxebizitza desegokia) hartzen ditu kontuan, eta kategoria horiek hamahiru kategoria operatibotan bereizten dira. Tipologia honek zenbait berrikuspen izan ditu 2005etik, azkenengoa 2017an izanik.

1. taula. ETHOS, Europako Etxegabetasunaren eta Bizitegi-Bazterketaren tipologia (2017)

\begin{tabular}{|c|c|}
\hline & Bizitegi egoera \\
\hline \multirow[b]{2}{*}{ Etxerik gabe } & 1. Kalean bizi direnak \\
\hline & $\begin{array}{l}\text { 2. Larrialdiko ostatua. Egunean zehar kalean egoten dira baina gaua aterpean } \\
\text { pasatzen dute. }\end{array}$ \\
\hline \multirow{5}{*}{$\begin{array}{l}\text { Etxebizitzarik } \\
\text { gabe }\end{array}$} & $\begin{array}{l}\text { 3. Etxerik gabekoentzat aterpetxe eta zentroetan/aldi baterako bizitokietan } \\
\text { bizi direnak }\end{array}$ \\
\hline & 4. Emakumeentzako aterpetxeetan daudenak. \\
\hline & 5. Asilo-eskatzaile eta etorkinentzako bizitokietan daudenak. \\
\hline & 6. Instituzio penal edo medikoetatik irten direnak. \\
\hline & $\begin{array}{l}\text { 7. Epe luzerako babesa (bizitokia) jasotzen duten pertsonak etxerik gabeko } \\
\text { pertsonak direlako. }\end{array}$ \\
\hline \multirow{3}{*}{$\begin{array}{l}\text { Etxebizitza } \\
\text { ez-segurua }\end{array}$} & 8. Edukitza ez-seguruko araubidean bizi direnak \\
\hline & 9. Etxegabetze-mehatxupean bizi direnak \\
\hline & 10. Indarkeria domestikoaren mehatxupean bizi direnak. \\
\hline \multirow{3}{*}{$\begin{array}{c}\text { Etxebizitza } \\
\text { desegokia }\end{array}$} & 11. Aldi baterako eta egitura ez konbentzionaletan bizi direnak. \\
\hline & 12. Bizitoki desegokia \\
\hline & 13. Pilaketa-egoera larrian bizi diren pertsonak \\
\hline
\end{tabular}

Iturria: norberak egina FEANTSA-ko (2017) tipologia jarraituz. 
ETHOS tipologia lagungarria suertatzen da errealitate zabal eta heterogeneoago bateraino heltzeko. Halaber, tipologia honek ahalbidetzen du aurreko ikuspegian ikusezinean geratzen ziren zenbait egoera kontuan hartzea. Adibidez, emakumeen kasuan haien presentzia handiagoa izan daitekeen beste egoera batzuk agerian jartzen ditu.

\subsection{Bizitegi bazterkeria genero ikuspegitik}

Aurretik aipatu den modura, ETHOS tipologiak ordura arte estatistika edo analisietan ezkutuan mantendu ziren zenbait bizitegi bazterketa egoera ikusgarri egiten ditu: etxebizitza ez segurua eta etxebizitza desegokia. Urteetan zehar etxebizitza zein bizitegi bazterkeriaren inguruan egin diren ikerketetan eta bideratu diren politika publikoetan ikuspegi androzentrikoa nagusitu da (Matulic; Munté eta De Vicente, 2020; Savage, 2016). Ikerketak espazio publikoan zentratu izan ohi dira non bizitegi bazterketan dauden gizonezkoen presentzia handiagoa den eta, ondorioz, emakumeen errealitatea ikusezin bihurtu da. Bizitegi bazterkeria soilik kalean lo egiten duten pertsonetara edo aterpeetan bizi direnetara murrizterakoan, emakumeen problematika ez da kontuan hartzen, ezkutuan geratzen da, Sales eta Guijarro-k azaltzen duten bezala:

Ikusten ez den etxegabetasun bat dago, eremu domestikoan gertatzen dena, kaletik kanpo eta bizitegi-prekarietateko egoera larriak dakartzana, bide publikoan gauzatu ez arren, bizitza-proiektu autonomo bat izateko gaitasuna eta muturreko pobreziaegoeretatik irteteko aukerak mugatzen dituena. (Sales eta Guijarro, 2017:100)

Ikerketa honetan, zehazki, ETHOS tipologiaren etxebizitza ez-segurua kategoria barruan aurkitzen den 10. bizitegi egoeran arreta jarriko da: indarkeria domestikoaren mehatxupean bizi direnak. Testuinguru honetan bikoteak eragindako indarkeria emakumeen bizitegi bazterketarako kausa nagusia dela izendatzen da (FEANTSA, 2019). Terminologia aldetik, ordea, hurrengo orrietatik aurrera aldaketa bat proposatzen da. FEANTSA-k erabiltzen duen indarkeria domestikoa kontzeptuaren ordez genero indarkeria kontzeptua erabiliko dut arazoa politizatzeko helburuarekin.

Genero indarkeriaz aritzean ulertzen da egiturazko izaera duen indarkeria bat existitzen dela, zeina ezin den interpretatu kasu isolatu eta indibidual bezala (Barrère,2008). Legalki, 1/2004ko Lege Organikoaren arabera genero-indarkeria honela definitzen da: gizonezko batek emakumezko bati ezartzen dion biolentzia beti ere bikote badira edo iraganean izan badira (Magro Servet, 2019). Definizio legal honek ez du kontuan hartzen genero indarkeriak adierazpen anitz dituela eta esparru ezberdinetan gauzatu daitekeela bikote-harremanez gain, izan familian baita lan eta gizarte inguruneetan ere. Gizonezkoen indarkeria emakumeekiko nahiko arrunta eta errepikakorra da gizarte-egitura gisa ulertu ahal izateko (Miller eta Du Mont, 2000). Hala ere, ikerketa honetan, ikuspegi kritiko-feminista batetik, genero indarkeria kontzeptua erabiliko da. Honekin esan nahi dudana da ez dela eufemismo gisa erabiliko eta, generoaren ustezko neutraltasunaren azpian, botere-kon- 
notazioa ez dela galduko (Osborne, 2009:32). Are eta gutxiago ere, genero-indarkeria erabiltzean ez dut kontsideratuko berdin eragin diezaiokeela gizon zein emakumeei. Gainera biolentzia hura ezin da mugatu soilik agerikoak diren modu esplizituetara, zeren horiez gain modu gehiago daude hurrengo taulan antzematen den bezala:

2. taula. Genero indarkeriaren iceberg-a

\begin{tabular}{|c|c|c|c|}
\hline \multirow{3}{*}{$\begin{array}{l}\text { Genero } \\
\text { indarkeria }\end{array}$} & Agerikoa & $\begin{array}{l}\text { Hilketa, eraso fisikoa, bortxaketa, sexu-abusua, garrasi } \\
\text { egitea, mehatxatzea, iraintzea. }\end{array}$ & \multirow{2}{*}{$\begin{array}{c}\text { Modu } \\
\text { esplizituak }\end{array}$} \\
\hline & \multirow{2}{*}{$\begin{array}{l}\text { Ez- } \\
\text { agerikoa }\end{array}$} & $\begin{array}{l}\text { Umiliatzea, mespretxatu, gutxietsi, baztertu, xantaia } \\
\text { emozionala, errua egotzi. }\end{array}$ & \\
\hline & & $\begin{array}{l}\text { Umore sexista, kontrola, publizitate sexista, } \\
\text { ikusezintasuna, lengoaia sexista, baliogabetzea, } \\
\text { mikromatxismoak. }\end{array}$ & $\begin{array}{l}\text { Modu } \\
\text { burutsuan }\end{array}$ \\
\hline
\end{tabular}

Iturria: norberak egina Amnistia Internacional-eko irudi batetik abiatuta.

Kontuan izanik genero indarkeria dela emakumeen bizitegi bazterketan zuzenkien eragiten duen fenomenoa, aurkezten den aukeretako bat erasotzailearekin partekatzen den etxebizitzatik joatea da. Batzuetan aukera hori ez da posiblea izaten. Beste batzuetan, norberaren etxeko indarkeria-egoera horretatik ihes egiten saiatzea da, indarkeria sufrimenduaren aurrean berez oso txarra den bizitegi-egoerak okerrera egitearen arrazoia (Fundación Atenea, 2018). FEANTSA-ko (2019) txosten batek azaltzen duen bezala, emakumeek badakite kalean bizitzeak haientzat suposatzen dituen egoera zaurgarria zein arrisku handiak, batez ere, indarkeria-motaren bat jasateko arriskuak, agerikoena, zalantzarik gabe, sexu-indarkeria eta bortxaketa dira, baina ez daude indarkeria fisiko edo psikologikotik salbuetsita. Txostenean aipatzen den bezala, beldur horrek, kalea emakumeentzat etsaitasunezko leku gisa hautemateari erantzuten dio, eta bertan indarkeria jasatea oso litekeena da. Beldur hori dela eta, emakumeek hainbat estrategia abiarazten dituzte kalean bizitzen amaitzeko aukera ekiditeko (Fundación Atenea, 2018). Hori dela eta, emakumeen bizitegi bazterketa nolabait eremu pribatuan «ezkutatzen» da, hau da, bizitegi bazterketan dauden pertsonei laguntzeko zerbitzu konbentzionaletatik kanpo gertatzen da (FEANTSA, 2015):

Ikusezintasun horren emaitza nabarmenetako bat etxerik gabeko pertsonei arreta emateko politikak ikuspegi maskulinotik diseinatu direla da, espazio publikoan denbora gehien egoten den bizitegi-bazterketaren eraginpean daudenei arreta emanez, gehienbat gizonak. (Sales eta Guijarro, 2017:83)

Hau lotuta dago aurretik sexu-abusu edo genero indarkeria esperientziak bizi dituzten emakumeek haien etxetik joaten direnean nahiago izaten dutelako ez mistoak diren aterpeetara joatea. Egoera hau kontuan izanik, FEANTSA-k (2007) defendatzen du emakumeentzat seguruak diren espazioak sortzea elkarren esperientziak komunikatzearen bi- 
dez ahaldundu daitezen. Gainera, baliabide espezifiko hauek emakumeei segurtasuna eskaintzen diete indarkeria matxistaren aurrean (Bizitegi, 2019).

\section{TESTUINGURUA}

2020eko martxoaren 14an, Pedro Sánchezek, Estatu espainiarreko gobernuko presidenteak, alarma egoera deklaratu zuen, Estatuko Aldizkari Ofizialean argitaratutako 463/2020 Errege Dekretuaren bidez, SARS-CoV-2 koronabirus pandemia kontrolatzeko ez-ohiko neurri gisa. Munduko Osasun Erakundeak dagoeneko 2020ko martxoaren 11ean SARS-CoV-2 koronabirusak eragindako osasun publikoko larrialdi-egoera nazioarteko pandemia kontsideratu zuen.

Alarma-,salbuespen- eta setio-egoerei buruzko ekainaren 1eko 4/1981 Lege Organikoaren laugarren artikuluko b) idatz-zatiak ahalmena ematen dio Gobernuari, Konstituzioaren 116.2 artikuluak esleitzen dizkion ahalmenak erabiliz, alarma-egoera deklaratzeko, estatuko lurralde osoan edo zati batean, normaltasunean aldaketa larriak eragiten dituzten osasun-krisiak gertatzen direnean.Testuinguru juridiko honek ahalbidetu egiten du Sánchezen gobernuak kutsatzeak murrizteko neurriak hartzea. Hilabete hauetan guztietan zehar lanabes juridiko ezberdinak baliatu dira horretarako: koarentena, mugikortasun murrizpenak, etxeratze-aginduak, besteak beste.

Aplikatu diren neurri horiek, ordea, etxebizitza izan dute ardatz nagusitzat. Honen adibide argiena aurretik aipaturiko lege eta dekretuaren barnean 2020ko martxoan ezarritako etxeko itxialdia da. Bide honetatik doa ere Gobernu zentralak zein autonomikoek zabaldutako mezua, \#NiEtxeanGeratukoNaiz bezalako traolarekin, etxean seguruago egongo bagina bezala. Aurretik aipatu den moduan, etxebizitza ezin dugu ulertu gatazkarik gabeko espazio armoniatsu gisa, zabaldutako segurtasun mezu hori ez delako bete biztanleriaren zati esanguratsu batean.

Honi lotuta, 1. Grafikoak erakusten duenez, eraildako emakumeen datuak larria izaten jarraitzen duen arren, azken hamar urteetako kopuru txikiena izan zen 2020ekoa eta nolabait 2016. urtetik aurrera hasi zen goranzko joerarekin hausten du. Horrez gain, duela hamar urte, 2010ean, eraildako emakumeen zifrarekin alderatuz, beherakada nabarmena da. Baina datu horiez haratago joan eta 016ra deiak aztertuez gero, datuek erakusten dute 2016 eta 2020 urteetan erailketa matxista kopuru txikienak gauzatu arren, azken hamar urteetan 016ari dei gehien erregistratutako urteak direlarekin. Estatistika honek frogatzen du ge-nero indarkeriaz aritzean ezin garela mugatu agerikoak diren modu esplizituetara (kasu honetan erailketak) ez-agerian eta modu burutsuan ere burutzen baita, aurretik aipatu den bezala. 
1. grafikoa. Erailketa matxistak eta 016ra deiak 2010-2020 urteen bitartean

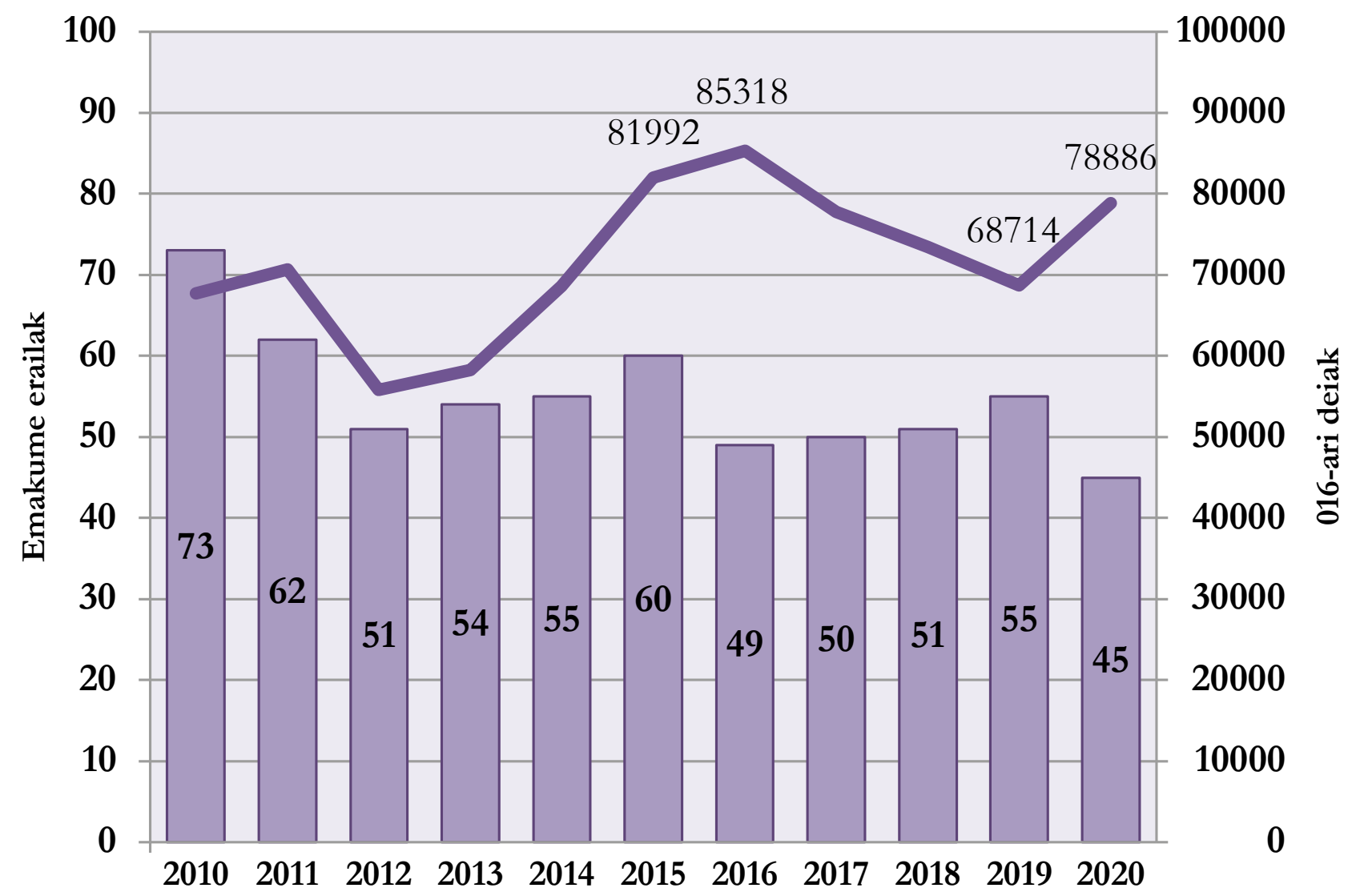

Iturria: norberak eginikoa Berdintasun Ministerioko Genero Indarkeriaren aurkako ordezkaritzako datuetan oinarrituta.

016a Berdintasun Ministerioak, Genero Indarkeriaren aurkako Gobernuaren Ordezkaritzaren bidez, eskaintzen duen telefono zerbitzua da genero indarkeriaren inguruko informazioa zein aholkularitza juridikorako. Azken hamar urteetan 2016a izan da 016ari dei gehien egin diren urtea, 2015arekiko \%4 igoz dei kopurua. Iazko urtean, bestalde, 2019arekiko dei kopurua \%15 areagotu zen eta azkenaldiko beheranzko joerarekin hautsi zuen. Honek lotura zuzena du SARS-CoV-2 pandemia garaian harturiko neurriekin. Munduko Osasun Erakundeak (2020) azaltzen duen bezala, emakumeen aurkako indarkeria areagotu egin da itxialdian zehar. Etxean geratzeko aginduaren aurrean, abusuzko harremanetan dauden emakumeek indarkeria pairatzeko probabilitate handiagoa dute. Gainera, erasotzaileak SARS-CoV-2 koronabirus pandemiaren kutsatze egoerak sorturiko beldurra erabili dute emakumeek etxetik ihes ez egiteko (Kofman eta Garfin, 2020).

Bestetik, 2. Grafikoko datuak erakusten du, 2019an 016eko deien inguruko datuak nahiko egonkorrak direla urte osoan zehar. Hala ere, iazko datuekin alderatuz gero, antzeman daiteke 2020an dei kopuruan gorabeherak daudela hilabeteen arabera. Nabarmendu beharrekoa da azken urteko apirilean 2019koan baino \%61 dei gehiago egin zirela 016ra. Aipatzekoa den gorakada da SARS-CoV-2 koronabirus pandemiaren aurkako prebentzio neurri gisa aplikaturiko etxeko itxialdiaren ondorioa da. Gainera, neurri honen harira, 
kontuan izan beharrekoa da itxialdiko agindu garaian genero indarkeriaren biktimak erasotzailearekin hurbiltasun konstante eta etengabean egoteak ia ezinezkoa egin zezakeela laguntza lortzeko mezuak eta telefonoak erabiltzea (Kofman eta Garfin, 2020). Beraz, baliteke dei kopurua baino handiagoa izatea laguntza edo asistentzia behar zuten emakumeak.

2. grafikoa. 016ari egindako genero indarkeria deiak 2019 eta 2020 urteetako hilabetee$\tan$.zehar

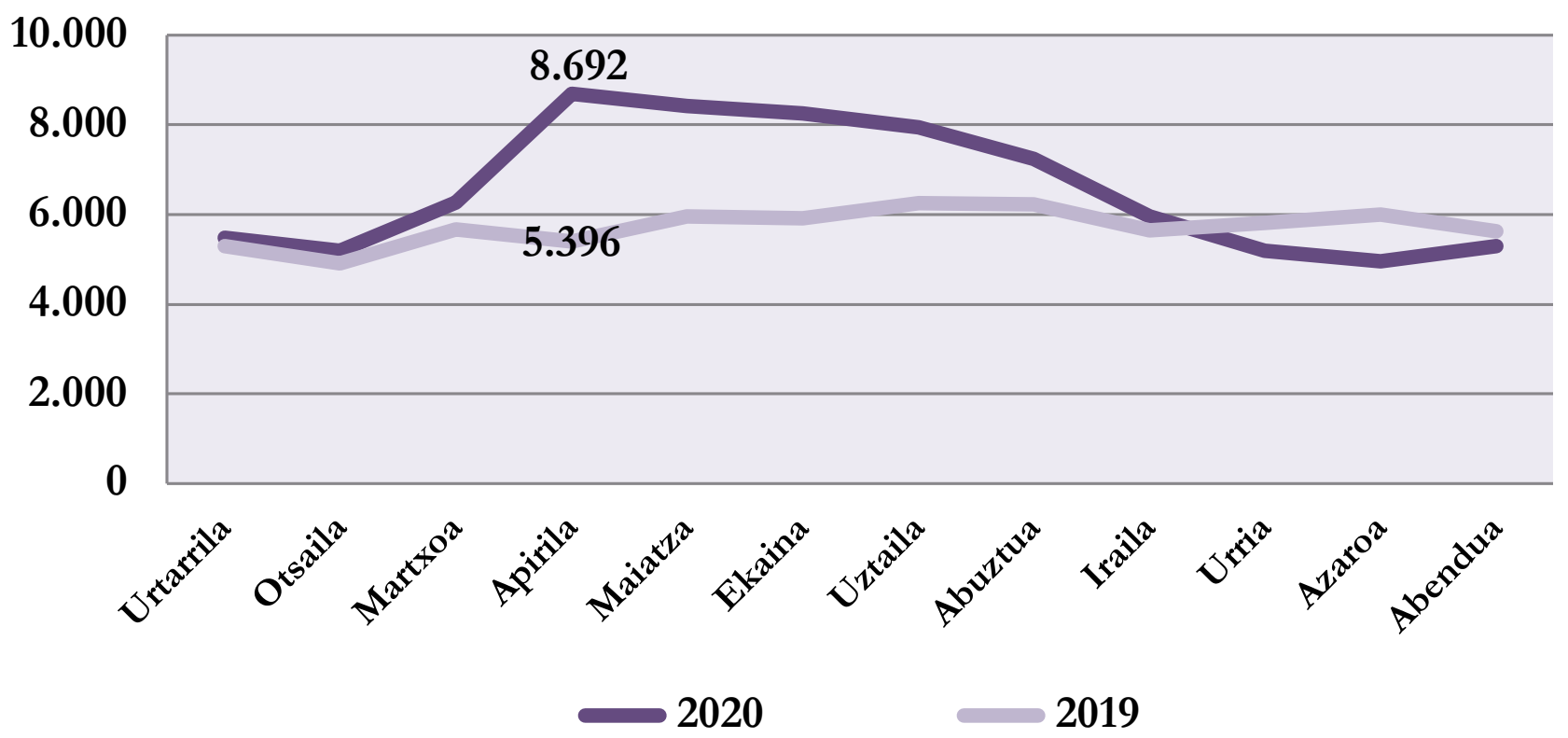

Iturria: norberak eginikoa Berdintasun Ministerioko Genero Indarkeriaren aurkako ordezkaritzako datuetan oinarrituta.

Halaber, Munduko Osasun Erakundearen (2020) arabera itxialdi aginduarekin emakumeen sare sozialak eteteaz gain, indarkeria matxista biziraun dutenentzat zerbitzuak gutxitu egin dira. Itxialdiak oztopatu egin die genero indarkeria pairatzen duten emakumeei haien etxebizitzetatik kanpo dituzten zaintza edo elkartasun espazioetara batzea eta honek haien zaurgarritasun egoera larriagotu egin du. Zerbitzu gehienak pandemiari aurre egitera bideratzean, emakumeentzako ezinbestekoak izan daitezkeen zenbait zerbitzu ez dira lehenetsi edo ez dira funtsezkoak kontsideratu (John; Casey; Carino eta McGovern, 2020). Honi lotuta, Munduko Osasun Erakundeak (2020) kezka adierazi du genero indarkeriaren oinarrizko osasun zerbitzuak pandemiari aurre egin ahal izateko desbideratuak izateko aukeraren inguruan. Honi gehitu behar zaio aplikatu beharreko distantzia sozialaren neurriak direla-eta, zenbait aterpe ez-mistoek edukiera murriztu behar izan dutela (Kofman eta Garfin, 2020). 


\section{DISEINU METODOLOGIKOA}

\subsection{Epistemologia feminista}

Ikerketaren helburu nagusiak bizitegi bazterketaren ikuskera androzentrikoa gainditzea eta genero indarkeria dela-eta etxebizitza ez seguruan bizi diren emakumeen bizitegi egoerak ikusgarri egitea direla kontuan hartuz, ikerketa hau epistemologia feministaren markoan koka dezakegu.

Ikuspegi feminista kontrajarri egiten zaio hegemonikoa izan den ikuspegi positibistari, metodologia feministek errealitate sozialera hurbiltzeko beste modu batzuk balioesten dituztelako. Halaber, giza biztanleriaren zati baten bizipenak orokortzen dituzten «egiarako bide» androzentrikoak zalantzan jarri ditu ikuspegi feministak (Hawkesworth, 2012:93). Gainera, ezagutzaren ekoizpenari buruzko premisa positibistek ez bezala, ikerketa «zientifikoaren» dimentsio politikoa onartzen du. Arrazoi horiek bultzatu naute ikerketa hau ikuspegi feministaren markoan kokatzera.

Gandarias eta Gartziak (2015) aipatzen duten modura, ikuspegi feministak ezagutza zientifikoa txertatzen den testuinguru sozial eta historikoen berezko botere eta menderatzeharremanek zeharkatzen duten praktika sozial gisa aldarrikatzen du. Beste behin positibismoari kontrajarriz, ezagutza objektibo, unibertsal eta judizio baliorik gabekoaren aurrean, behaketa oro, analisi oro, kokatuta dagoela babestuko dute.

\subsection{Narratiben Ekoizpenak}

Narratiba ekoizpenen proposamen metodologikoa Balasch eta Montenegro-rena da (2003) eta Donna Harawayren (1991) ezagutza kokatuen ikuspegi feministan oinarritzen da. Ezagutza kokatuen ikuspegia begiradaren partzialtasuna onartzetik abiatzen da. Partzialtasunaren eta ezagutzaren lokalizazioaren aldeko apustua proposatzen du aukera gisa: kokapena da garrantzitsuena, hitz egiten dugun leku horretatik posizionatu behar gara (Haraway,1991). Objektibotasuna, beraz, ez da lortzen bizi garen mundutik aldenduz ikuspegi positibistak defendatzen duen bezala, baizik eta gure kokagunea ezagutuz eta daukagun posiziotik erreflexiboak izaten (Tacoronte, 2013).

Ikerketa-prozesuan sortzen diren narratibak ikertzailea eta parte-hartzailea ikertutako fenomenoaz hitz egiteko elkartzean sortzen den jardueraren emaitza dira. Narratiba hauek gainera, toki kokatu batetik egindako jarduerak dira, jarraian Pujol eta Montenegro-k azaltzen duten modura:

Narratibak ez dira egungo testuinguru kulturaletatik isolatutako ekoizpen indibidualak: narratiba horiek ekoizten diren testuinguru soziokulturala erreproduzitu, zalantzan jarri, elikatu, eraldatu, ironizatu egiten dute. Eraikitzen ditugun eta sor- 
tzen gaituzten narrazioek errealitate-ondorioak dituzte, eta aldi berean, hainbat modutan interpretatu eta irakur daiteke. (Pujol eta Montenegro, 2013:16)

Nahiz eta ikerketa honen helburuetako bat genero indarkeria dela-eta etxebizitza ez seguruetan bizi diren emakumeen bizitegi bazterketa egoerak ikusgarri egitea den, ezin dugu nahastu ikusgarri egiteko intentzio hori «ahotsa emateko» intentzioarekin. Hitz edo ahots ematearen nozioak harreman asimetrikoa ezartzen du parte-hartzailearen eta ikertzailearen artean, ulertuz azken honek baduela legitimitate akademiko zein zientifikoa lehenari hitza eman edo kentzeko, eta ez alderantziz (Balasch eta Montenegro, 2003). Teknika honen bidez, ordea, akademiaz haratago dagoen ezagutzara iristeko asmoa nuen. Azken finean, ezagutza narratiboak bizitzaren anbiguotasuna eta konplexutasuna ulertzeaz gain, egiaren, errealitatearen eta ezagutzaren ikuspegi tradizionalei aurre egiteko ahalbidetzen gaitu (Gandarias eta Gartzia, 2015).

\subsection{Narratiben profila}

Ikerketa honek lau narratiba biltzen ditu. Horiek guztiek partekatzen duten ezaugarria genero indarkeria pairatzen duten emakumeekin lan egiten dutela da. Hasierako asmoa genero indarkeria jasaten duten emakumeak elkarrizketatzea zen, baina gogoeta epistemologiko baten ondoren ondorioztatu nuen ez zela egokiena. Nire gizonezko identitateak baldintzatu zezakeen ikerketa bera eta ezagutza berrien sorrera, parte-hartzaileek nirekin izango luketen komunikazioa deserosoa izanik.

Hasiera batean, Bilboko elkarteetara mugatzea erabaki nuen arren, ikerketak aurrera egin ahala, zailtasunak zailtasun, lagin-eremua zabaltzea erabaki nuen Bilbo Handira. Honela, Barakaldoko elkarte bat gehitzea erabaki nuen. Beheko taulan ikus daitezke ikerketan parte hartu duten elkarteak eta hauen kokapena:

3. taula. Narratiben profila

\begin{tabular}{|l|l|}
\hline \multicolumn{1}{|c|}{ Elkartea } & \multicolumn{1}{|c|}{ Elkartearen kokapena } \\
\hline Haize Berria & Bilbo, Bizkaia \\
\hline Argitan: Emakumeen Aholku Etxea & Barakaldo, Bizkaia \\
\hline Erain Psikoterapia Humanista Gunea & Bilbo, Bizkaia \\
\hline La Posada de los Abrazos - Besarkatuz & Bilbo, Bizkaia \\
\hline
\end{tabular}

Azken finean, proposamen epistemologiko honen helburua ez da errepresentazioa ezta orokortzea ere. Narratiba hauen bidez ez dut erantzun edo teorizazio homogeneo batera iritsi nahi, etxebizitza ez segurua eta genero indarkeriaren intersekzioari buruzko hainbat ikuspegi jaso nahi ditut, Gandarias eta Gartziak (2015:101) aipatzen duten bezala «azterketa-fenomenoaren ezagutza difraktatu eta zabaldu ahal izateko». 


\section{EMAITZAK}

Hurrengo atal honetan narratiben bizipenak, ikuspegi komunak zein ezberdinak, eta egindako ekarpenak bilduko ditugu. Horretarako, atal teorikoan eta testuinguruan azaldu ditudan iturri eta datuez eta nire ekarpenez baliatuko naiz, parte-hartzaileen kontakizunekin batera etxebizitza ez seguruko bizitegi bazterkeria eta genero indarkeriaren intersekzioaren analisia ehuntzeko asmoarekin.

\subsection{Baliabideak}

Administrazio Publikoak genero indarkeria jasaten duten emakumeentzako eskaintzen dituen baliabideei dagokionez, protagonisten gehiengoak iritzi kritikoa azaldu du. Beharbada ahots guztietatik gehien ezberdintzen dena Haize Berria-ko kidearena da, zeinaren aburuz «maila instituzionalean baliabide dezente daude (...), uste baino gehiago». Honen aurrean, ordea, Argitan-eko kideak guztiz kontrako iritzia du kontsideratzen baitu ez dagoela baliabide espezifikorik emakume batek identifikatzen duenean indarkeria jasaten ari dela eta erasotzailearekin batera etxebizitza berean bizi dela. Ildo beretik jarraitzen dute Besarkatuz-eko kideek administrazioak herritarrengandik duen distantzia urruna salatzerakoan: "Administrazioa bere airera doa, laguntzak muntatzen dituzte beraiek nahi duten bezala. Laguntza horiek ez daude pentsatuta artatzen duten edo ustez baliabideak beharko dituzten biztanleentzat. Hor goian daudenen erosotasunerako pentsatuta daude, egunerokotasunean bizi ez direnen eta hemen behean gauzek nola funtzionatzen duten ez dakitenen erosotasunerako.»

Alde horretatik, Haize Berria-ko kideak defendatzen du eskaintzen diren baliabideetan ez duela mugarik aurkitu eta egoeratik ateratzen laguntzen dutela: «Nahikoa dira emakumeei laguntzeko eta aurrera egiteko.» Erain-eko langileak, bere aldetik, azaltzen du baliabideek emakumea berbiktimizatzeko joera dutela: «Profesional asko dago gauzak ondo egiten dituena baina, azken finean, sistemak bere izaeragatik emakume askok biolen-tzia berpairatzea dakar.» Besarkatuz-etik, bestetik, kritikatzen dute ez dagoela emakume bakoitzaren partikulartasuna errespetatzen duen espaziorik: «Zaurgarritasunak edo in-darkeriak bizitzen ari diren zenbait emakume ezin dira espazio batzuetara sartu, ez bai-tago beren hizkuntzan arreta eman diezaiekeen profesionalik. (...) Kontakizuna par-teka tzea, auto-estimua lantzea, autokontzeptua, barnekoa kanporatzea... hori guztia blokeatuta geratzen da.» Honi Argitan-eko kideak gehitzen dio emakumeek erabakitzen badute ez dutela bat egiten Administrazio Publikoak ezarritako bide ofizialarekin, hau da erasotzailea salatzen hastearekin ekiten zaion prozesu luzearekin, ez direla eskaintzen di-tuzten baliabideetatik kanpo geratu behar, orain arte gertatzen den bezala.

Bide ofizialari dagokionez, Administrazio Publikoak eskaintzen dituen baliabide horiek (aholkularitza judiziala, talde psikologikoa...) eskuragarri izateko aurretik salaketa jarri beharra dago, Haize Berria-ko kidearen arabera, bestela zailtasunak egoten omen dira ka- 
suak identifikatu ahal izateko. Honen aurrean, Argitan elkarteak hurrengoa gogorarazi nahi du: "Argitan-era etortzen diren emakumeen \%80ak baino gehiagok ez du salatzen eta, beraz, ez du ofizialki biktima gisa kontatzen. Sortzen zaizkien konplikazio guztien ondorioz (prekarietatea, pobrezia, egoera zailak, zauden lekutik irteteko aukerarik ez izatea), ez dute inoiz bide ofizial hori hartuko.» Kontuan izan behar dugu, batzuetan, erasotzailearekin partekatzen den etxebizitzatik joateko aukerarik ez dutela izaten eta, beste batzuetan, norberaren etxeko indarkeria-egoera horretatik ihes egiten saiatzea da, indarkeria sufrimenduaren aurrean berez oso txarra den bizitegi-egoerak okerrera egitearen arrazoia (Fundación Atenea, 2018).

Pandemiak baliabide horien eskaintzan izan duen eraginaren inguruan, beste behin Haize Berriaren testigantza bereizi egiten da gainontzeko protagonistekin: «koronabirusaren pandemian baliabideek eskuragarri egoten jarraitu dute, baina genero indarkeriaren biktima diren emakumeak ez dira hurbildu.» Argitan-eko kideak, aldiz, uste du Administrazio Publikoaren baliabideak urriak izan direla eta, gainera, azpimarratzen du beraren elkartean pandemia osoan zehar ez ziotela lan egiteari utzi, kontsideratzen baitzuten haiek eskaintzen zuten zerbitzua ezinbestekoa zela. Honekin bat egiten dute Besarkatuzeko lagunek zeintzuen jarduera pandemian zehar, Argitan-en kasuan bezala, ez den gelditu, areagotu baizik. Baliabide urritasun hau salatzeko Argitan-eko langileak hurrengo adibidea jartzen du: «Barakaldoko Udalean etxerik gabeko emakumeentzako berariazko etxebizitza bat zegoen, pandemiaren hasieran zazpi emakume bizi zirena. Baliabide hori ixteko aitzakia izan zen hezitzaileek eta bertan zeuden gizarte langileek kiroldegiko aterpetxe mistoa artatu behar zutela, non 50 gizon baino gehiago artatu zituzten. Egoera bereziki zaurgarrian dauden emakume horiek baliabide misto batean amaitu behar izan zuten, kiroldegi batean 50 gizon baino gehiagorekin. Izan ere, zazpi emakume horietatik bi, baliabidea itxi zutenean, desagertu egin ziren beldurragatik, kiroldegi batean beste 50 gizonekin ez zutelako bizi nahi, sor zitezkeen arazoengatik eta haiei sortzen zitzaien beldurragatik.» Adibide honek agerian uzten du baliabidearen diseinu androzentrikoa, ez baititu kontuan hartzen emakume erabiltzaileak nola sentitu daitezken halako testuinguru batean. Kontuan izan behar da, aurretik sexu-abusu edo genero indarkeria esperientziak bizi izan dituzten emakumeak etxetik joaten direnean nahiago izaten dutela ez-mistoak diren aterpeetara joatea. Eta, ildo honetan, FEANTSAK (2007) urteak daramatza defendatzen emakumeentzat seguruak diren espazio ez-mistoak sortu behar direla elkarren esperientziak komunikatzearen bidez ahaldundu daitezen. Halaber, indarkeria matxistaren aurrean, emakumeentzako baliabide espezifiko hauek segurtasuna eskaintzen diete (Bizitegi, 2019).

Erain-eko kidearen arabera, ordea, pandemiako itxialdiak ez ditu bakarrik gauza txarrak ekarri. Haren ustez, ziurgabetasunean bizi ziren zenbait emakumeri egonkortasun epe bat suposatu die, larrialdiko errekurtsorako egonaldia luzatu egin zaielako. Hala ere, larrialdiko harrera-zerbitzu hauen inguruan protagonisten gehiengoak jarrera kritikoa erakutsi du. Besarkatuz, Argitan zein Erain-eko kideek bat egiten dute baliabide honek emakumeetan itxiera sentimendua eragiten diela aipatzean, kontrolatuta eta infinituraino zelatatuta 
amaitzen baitute. Argitan-eko langileak ez ditu bidezkoak ikusten emakumeek jasan behar dituzten mugak: «Indarkeria-egoera batetik edo tratu txarreko egoera batetik ateratzen dira eta administrazioak ikuskatu egiten ditu (...) Benetan, zaintzapean, bakartuta edo askatasun mugatuarekin egon beharko lukeena erasotzailea izan beharko litzateke, eta ez emakumea.» Ildo beretik, Besarkatuz-etik salatzen dute: «emakumeak eremu pertsonalean eta sozialean mugatuta daude, eta erasotzaileak, berriz, bizitza arrunta bizi dute.»

Erain-eko langilearen iritziz, emakumeen gaineko gehiegiko zaintza zein kontrol honen ondorioz berbiktimizazio prozesu bat gertatzen da zeina biolentzia sistematikoaren parte den: «Emakumeak errekurtso horietan itxita sentitzen dute beraien burua, kartzela batean bezala, kontrola galduta.» Antzekoa aipatzen dute Besarkatuz-eko kideek ikuspegi mendebaldarretik diseinatutako espazio hauen formatuen mugei zein protokoloei buruz aritzean. Emakume askok zailtasunak izan omen dituzte ulertzeko baliabide horiek zein estuak edo mugatzaileak diren. Honela, Erain-ekoak aipatutakoaren harira, Besarkatuz-etik diote emakumeek hurrengoa esan ohi dietela: «Nik ez dut zentro batera joan nahi kartzela bat delako eta dagoeneko kartzela batetik nator.»

Iristen diren baliabide horietan laguntza, haiek kontatu beharrekoa entzuteko prestutasuna eduki beharko lukete, baina errealitatea, ordea, ezberdina da: kontrola eta askatasun eza. Gainera, Besarkatuz-en salatzen dutenaren arabera, baliabide hauetako langileen aldetik berotasuna eta hurbiltasunaren ordez, kasu batzuetan, «kontrol eta autoritarismo hutsa» jasotzen dute. Halaber, programa hauek markatutako denbora zein helburuak jarraitu behar izateak, Besarkatuz-ekoen ustez emakumeei agentzia kentzen die, zeren, azken finean, ezin dute haien prozesu pertsonala aurrera eraman. Hala ere, Erain-eko kidearen ikuspegitik, nahiz eta kontsideratzen duen larrialdiko errekurtsoek berbiktimizaziorako joera dutela, batzuetan hauen beharra dagoela azpimarratu du: «Batzuetan zure historia pertsonalera berriro ez bueltatzeko, biolentzia toki horretara ez bueltatzeko, batzuetan hobea da errekurtso itxi batean egotea.»

Baliabideen atalarekin amaitzeko interesgarria da, pandemia testuinguruan Administrazio Publikoaren baliabideak eskuratzeko areagotu egin den digitalizazioak etxebizitza ez seguruan genero indarkeria jasaten ari diren emakumeetan izandako eraginean arreta jartzea. Protagonisten gehiengoak ikuspegi eszeptikoa adierazi du digitalizazioaren areagotzeari dagokionez. Haize Berria-ren aburuz «genero indarkeriaren biktima diren emakume askori eragin die. Kontuan izan behar da erasotzaileek dena kontrolatzen dutela. Ordenagailuaren pasahitza badute, zuk ezin duzu ezer eskuratu. Hau da, ez duzu telefonorik, ezin zara kalera atera, ez duzu Internetik. Orduan, erabateko itxiera da. Ez zaude fisikoki kateatuta, baina bai, ordea, psikologikoki.»

Argitan-etik ere aipatzen da errealitate hori non emakume batek indarkeria-egoera horretan ez dituen eskuragarri izango telefonoa edo ordenagailua. Honek guztiak ikaragarri zailtzen du edo ezinezko bihur dezake emakumeek baliabide horietara sarbidea eskuratzea eta, gainera, gehitzen du: «dena informatizatuta dago eta guztiek ez dute informatika- 
ren munduan funtzionatzeko gaitasunik. Beraz, zailtasun handiak suposatzen ditu.» Honekin ados daude Besarkatuz-eko kideak zeintzuek hurrengoa gehitzen duten: «Hau guztia bazterkeria da, erabateko aporofobia. Gainera, emakumeei agentzia kentzen die, beti behar baitute norbait herritar guztientzat egon beharko lukeen tramite bat kudeatu ahal izateko.» Azken finean, nahitaezko digitalizazioa beste oztopo bat da baliabideak eskuratzeko orduan eta konplexutasuna gehitzen dio tramitea kudeatzeko prozesuari. Hau guztiz lotuta dago «behartsuenei pasarazten zaien labirinto burokratikoarekin» (Mesa, 2019:9).

Bestetik, Besarkatuz zein Argitan-ek bat egiten dute emakumeei aurrezko aurreko arreta eskaini behar zaiela adieraztean, telefono bidez ez baita lortzen arazo guztiak konpontzerik, esaterako, tramite ulermenari dagozkion arazoak. Honela Argitan-eko kideak hurrengoa gehitzen du: «Funtsezko zerbitzu gisa, supermerkatu eta farmazien antzera, gizarte-zerbitzuek eta emakumeei arreta emateko zerbitzuek aurrez aurreko arreta hori izan beharko lukete (...) Indarkeria jasaten ari diren emakumeek dituzten beharrei erantzungo dien kalitatezko zerbitzua izateko, jakina, zerbitzu pertsonalizatua izan behar du, 24 orduz baliabideak izango dituena, azkarra, eraginkorra eta irisgarria izango den premiazko arreta.»

\subsection{Koronabirusaren aurkako neurriak}

Pandemia honetan koronabirusari aurre egiteko aplikatu diren neurriek (etxeko itxialdia, deseskalatzea, etxeratze-agindua...) etxebizitza izan dute abiapuntutzat, ulertuta espazio seguru bat izango balitz bezala. Kontua da, genero indarkeria jasaten duten emakumeek haien etxebizitza ez dutela toki segurua kontsideratzen, kartzela baizik, Paglione-k (2006) azaltzen duen bezala. Etxea kartzela gisa ulertzearen metafora hori protagonistetako bik ere erabiltzen dute. Haize Berria-ko kideak, Paglione-ren ildo beretik, aipatzen du: «Aitzitik, pandemiako itxialdia biktimarentzako kartzela eta erasotzailearentzako askatasuna izan da. Hori oso argi utzi behar da. Berak berea egin du: emakumea erabat giltzapean eduki (...) Bera, zoritxarrez, «el puto amo» izan da.» Bestetik, Argitan-eko kideak Haize Berriakoa-ren antzera hurrengoa komentatzen du «itxialdian ezin ateratzeak kartzela bihurtu ditu indarkeria-egoera horretan dauden emakumeen etxeak.» Bi testigantza hauek argi uzten dute etxebizitzaren ideia mitifikatua gainditu beharra dagoela, jasandako erasoengatik emakumeek etxean egotearen sentsazioa galdu dezaketelako (Osuji eta Hirst, 2015).

Etxebizitza espazio segurutzat ulertzearekin ere oso kritiko agertu dira Besarkatuz-etik: «Beldurra askoz handiagoa da; izan ere, pandemian zehar iritsi diren mezuak deuseztatzaileak, blokeatzaileak eta beldurrezkoak izan dira, eta hori guztia hirukoiztu egiten da emakumea etxean bizitzen ari denarekin, ustez berarentzat espazio horrek segurua izan beharko lukeenean. Telefono zerbitzu horiek egon diren arren, etxean geratzeko esaten jarraitzen dute. Eta zer da ba etxea? Zein ulerkera dugu honetaz etxerik ez duen jendea dagoenean? Etxea duen jendea baina honela sentitzen ez duen jendea dagoenean? (...)» Gogoratu behar dugu etxebizitza duina etxebizitzaren adierazpen fisiko edo aspektu ma- 
terialez haratago doala, espazioaren segurtasuna eta bakea ere kontuan izan behar direla (Pisarello, 2003; Paglione, 2006). Gainera, Argitan-eko langilearen arabera etxebizitza espazio seguru gisa ulertzen duten koronabirusaren aurkako neurri hauen aplikazioaren ondorioz, atzerapen handia eman da indarkeria matxistaren sentsibilizazioari eta kontzientziazioari dagokionez, indarkeria matxista eremu pribatukoa, etxebizitzarena, familiarena eta emakumeena delako sentsazioa sortu baita; arazoa publikoa eta soziala denean.

Pandemiari aurre egiteko aplikatu diren neurriek etxebizitza ez seguruan bizi diren emakumeen indarkeria egoeran izandako eraginaren inguruan, alde batetik, Erain-eko kideak azaldutakoa gainontzeko protagonistetatik bereizi egiten da. Honek aipatzen du, kasu batzuetan, itxialdian zehar biolentzia baretu egin zela, hau da, ez zela areagotu: «Gizon batek etxean bere emaztearen aurka biolentzia gauzatzerakoan, batzuetan gizonak biolentzia justifikatu egiten du, esaterako, lanean txarto zegoelako (...) Eta orduan, horrelako egoerak ba agian, kasu batzuetan, lasaitu egin dira kanpoko liskar horiek konfinamenduan ez direlako egon (...) etxeko egoera hori lasaitu egin zen.» Aipatutakoak lotura izan dezake Ehrenreich eta English-ek (2010) aipatzen dutenarekin, hau da, gizonek bizitza pribatuan erakargarritasun sentimentala bilatzen dutela, lantokian aurkitu dezaketen hoztasun eta inpertsonaltasunaren aurrean.

Bestetik, gainontzeko protagonistek pandemiaren aurkako neurriek emakume horien indarkeria egoeran areagotu edo larriagotu dutela salatu dute, edo indarkeria pairatzeko probabilitate handiagoa izatea, Munduko Osasun Erakundeak (2020) azaltzen duen bezala eta 016ra egindako deien gorakadak erakusten duen moduan. Gogoratu behar dugu 2019arekin alderatuz, 2020ko apirilean, hilabete osoa itxialdian igaro genuen lehenean, \%61 dei gehiago egin zirela 016ra. Beraz, datuetan ageritakoak bat egiten du protagonista hauen narratibekin. Argitan-eko kidearen aburuz, itxialdian zehar indarkeria matxista areagotu egin da baina ez da hainbeste konfinamenduak sorturiko indarkeria izan, baizik aurretik gauzatzen zenaren biziagotzea suposatu du. Haize Berria-ko kidearen kasuan, esaterako, itxialdiaren ondorioz erasotzaileek emakumeekiko kontrol handiagoa izan dutela azaldu du: «Telefonoa kentzen dizu, ordenagailuko pasahitza dauka eta ez dizu ematen... Hiru hilabete izan dira egunean 24 orduz tratu txarrak eman dituenarekin bizitzen, inorekin hitz egin ezinik, seme-alabak eskolara eraman ezinik. Pandemiak mundu guztiari eragin dio, baina genero-indarkeriako egoera astungarria izan da.» Ildo beretik, Besarkatuz-etik ere komentatzen dute itxialdiaren ondorioz emakumeak isolatu egin direla, ezin baitzuten gertuko konfiantzako konpainia batengana jo laguntza eske. Honek lotura du Kofman eta Garfin-ek (2020) pandemiaren ondorioen inguruan burututako txostenean aipatzen dutenarekin: itxialdiko agindu garaian genero indarkeriaren biktimak erasotzailearekin hurbiltasun konstante eta etengabean egoteak ia ezinezkoa egin zezakeen laguntza lortzeko mezuak eta telefonoak erabiltzea.

Indarkeria jasaten duten emakumeek itxialdia haien erasotzaileekin igaro izanak edo isolamendu egoera honetan inorekin kontaktatzeko aukerarik ez edukitzeak, eraman gai- 
tzake pentsatzera erasotzailearen indarkeria psikologikoa areagotu egin dela. Beste behin, 016aren inguruko datuei erreparatuz, kontuan izan behar da nahiz eta 2020an erailketa matxisten beherakada bat eman den, asistentzia telefono horretarako deiak areagotu egin direla. Honek gogorarazten digu genero-indarkeria ez dela soilik agerikoak diren modu esplizituetara (sexu-abusua edo hilketa, esaterako) mugatzen, narratibetako protagonistek azaltzen duten bezala. Argitan-eko langileak hurrengoa aipatzen du: «Azken finean, begi morea erraz ikusten da, baina gizonek emakumeengan eragiten duten indarkeria psikologikoa ez da hain erraz ikusten. Eta jakina, pandemiaren eta itxialdiaren ondorioz, kontrolerako, xantaiarako eta umilazioetarako indarkeria psikologiko hori askoz ere gehiago hazi zen.»

Ildo honetan, aurretik aipaturiko Kofman eta Garfin-ek (2020) burututako txostenean aipatzen da erasotzaileek SARS-CoV-2 koronabirus pandemiaren kutsatze egoerak sorturiko beldurra indarkeria psikologikoko mekanismo gisa erabili dutela emakumeek etxetik ihes ez egiteko. Haize Berria-ko kideak, ordea, ez du uste hau honela izan denik: «Pandemiak berak sortu duen beldurrak, kutsatzeko beldurrak, ez du zaildu etxean gertatzen diren indarkeria-ziklotik irtetea. Etxean daukazunaren beldur baldin bazara, burutik pasa dakizuke: «Nahiago dut atera, birusa hartu eta hil eta egoera honekin amaitu.» Emakumeek atera egin nahi zuten, gaixotu eta hiltzera bada ere, egoera hura bizitzen jarraitu baino lehen.» Horrez gain, Argitan-en antzera, Haize Berria-ko kideak ere partekatzen du indarkeria psikologikoaren areagotzea baina, haren ustez, ez hori bakarrik, indarkeria fi-sikoak eta sexualak ere gora egin du. Besarkatuz-eko kideek antzeko iritzia dute: "pande-miak suminkortasun handiko prozesu pertsonalak ekarri zituen, askoz ezegonkortasun handiagoak, eta askoz ere prozesu gehiago egon ziren, zaurgarritasun gehiago, laguntza-dei gehiago izan genituen.» Erain-eko langileak, ordea, ez du uste orokortu daitekeen joera baten aurrean gaudenik. Adostasuna adierazten du, kasu batzuetan, biolentzia fiskoa, ber-bala, kontrola edo psikologikoa bezalakoak areagotu egin direla baieztatzean, baina, beste batzuetan, aurretik aipatu duen modura, indarkeria-egoeren egonkortasun edo erlaxazio bat antzeman dutela dio: «Biolentzia hauek guztiak transbertsalak direnez, ikus daiteke etxean biolentzia matxista jasaten duen emakume batek, bat-batean, konfinamendu ga-raian agian biolentzia fisiko gehiago ez jasatea eta «luna de miel» antzeko espazio batean sartzea. Kontua da, fase honetara pasatzea okerragoa dela gerora, errealitatera itzultze-rakoan mierda horrek guztiak jarraitu egingo duelako, baina latzago.» Komentatzen du, kasu batzuetan, sufrimendua edo biolentzia areagotu direla emakumeek zainketa sarerik ez zutelako eskura.

Azkeneko honekin lotuta, zaintza-sareei dagokionez, bai Argitan-eko kideak, bai Besarkatuz-ekoek hauen lana goraipatu nahi izan dute Administrazio Publikoaren gelditasunaren aurrean. Lehenengoaren arabera «administrazioak ez dira izan arazo horiek, beharrezko baliabide horiek, kudeatzeaz arduratu direnak; aitzitik, emakumeen sareak izan dira une horietan behar zuten laguntza izatea lortu dutenak.» Besarkatuz, bestalde, Bilboko San Frantzisko auzoan kokatuta dago eta aipatzen dute pandemian zehar bertan osaturiko auzo-sareak auzoko gizarte zerbitzuek baino jarrera, arreta eta mugimendu handiagoa 
izan zutela. Azkeneko hau kezkatuta salatzen dute: «Haien arabera, kolapsatuta zeuden eta telefonoz bakarrik artatzen zituzten. Emakumeari arreta zuzena emateko gai ez izatea, baizik eta telefono bat erabiltzea, lagundua sentitzeko aukera hori ez ematea, kezkagarria da.»

\subsection{Ahalduntze estrategiak}

Genero indarkeria jasaten ari diren emakumeei bideratutako ahalduntze estrategiei dagokienez, lau elkarteetako protagonistek bat egiten dute bakarrik ez daudela erakustea oso garrantzitsua dela. Besarkatuz-ekoek aipatzen dute sareak sortzearen beharra, emakume askoren arazo nagusia bakardadea baita eta pandemiaren ondorioz ezarritako itxialdiak isolamendu ekarri zien.

Indarkeria egoera horiek kasuistika indibidualei ordez, egiturazko arazo bati erantzuten diote (Miller eta Du Mont, 2000; Barrère, 2008). Haize Berria-ko kideak komentatzen du indarkeria jasaten ari diren emakumeek beraien onerako begiratu behar dutela, nahiz eta egoera horretan emakumeei berekoikeria iruditu: «Zuk ondo sentitu behar duzu besteak ondo sentiarazteko (...) Berekoikeria hitza jada negatiboa da, ezta? Ondo sentituko gara, barre egingo dut, pozik egongo naiz eta aurrera jarraitzeko borrokatuko dut.» Argitan-etik eta Erain-etik bat egiten dute estrategia horiek lanketa pertsonalaz haratago joan behar dutela, gizartean isla eduki dezaten. Lehenengoak, zehazki, dio "indarkeria bizi dugun sistema matxistaren egiturazko ondorio gisa ulertu behar dela. Beraz, alderdi kolektibo horrek eta kontzientziazio sozialak ere egon behar dute.» Bigarrenak, lehenak aipatutakoaz gain emakume haien historien zeharkakotasuna azpimarratzen du: « (...) egoera berdinean pertsona asko daudela eta agian, laguntza behar dutela ikusteko, begiak irekitzeko, ohartzeko biolentzia hauek pairatzea ez dela batere normala eta sozialki eredu guztia aldatu behar dugula, arazo soziala baita.» Horretarako, elkarteek lan egiten duten emakume bakoitzari zuzendutako ahalduntze estrategia ezberdinak bideratzen dituzte.

Lehenik, Haize Berria-ren kasuan, garrantzia ematen dio ahalduntze prozesuan jarraibide psikologiko, judizial edo polizialak jasotzeari. Honen harira, psikologo zein abokatuen bisitak izan ohi dituzte emakumeei lagundu ahal izateko. Horrez gain, aipatzen duen bezala "gehienetan ezer gabe geratzen dira (...) fisikoki ere haien itxura ez da oso ona izaten.» Egoera honi aurre egiteko, ahalduntze estrategien barruan, estetikari zein ile apaintzaileen bisitak izaten dituzte, hauek emakumeen itxura fisikoan aldaketak posible eginez. Komentatzen du aldaketa hauek emakumeak haiekiko pixkanaka seguruago sentiarazten laguntzen dietela. Bestetik, haien burua defendatzen irakasten dien gimnasio batera joaten dira, estrategi guzti horien barne. Tamalez, Haize Berria-ko kideak komentatzen du estrategiek ez dutela emakume guztiekin funtzionatzen, prozesu oso zaila baita: «Badira emakumeak aurrera ateratzen direnak, borroka egiten dutenak eta aurrera egiten saiatzen direnak, eta badira emakumeak erasotzailearekin itzuli direnak.» 
Bigarrenik, Argitan-i dagokionez, urtez urte auto-estimu tailerra egiten dute. Kontuan izanik genero indarkeriak emakume horien auto-estimuan izaten duen eragin negatiboa, hurrengoa aipatzen du tailerraren inguruan: «beti dago beteta, beti dugu itxaro-zerrenda, eta parte-hartzaileengandik jaso ohi dugun feedbacka oso ona da.» Azken finean, egoera horietan, aipatu berri dugun bezala emakumeek behar dutena da.

Hirugarrenik, Erain-en lanketa norbanakoan bakarrik zentratu ordez, norbanako hori parte den sisteman egiten da. Honela, ikuspegi komunitariotik bideratutako ahalduntze estrategien helburua «emakumeek kontzientzia hartzea, jakiteko haien jokaerak eta erlazio moduak nola aldatu behar dituzten, ez jarraitzeko biolentzia erlazio horietan edo egoera horiek etorkizunean ez berpizteko.» Ildo honetatik, aipatzen du talde tailerrak egiteaz gain, tailer psikoedukatiboak antolatzen dituztela non, Argitan-en antzera, auto-estimua lantzen diren, indarkeria jasan duten emakumeen bestelako sentimenduekin batera. Bilkura hauek kolektibo saretzeaz gain, emakumeen arteko ahalduntzea bultzatu nahi dute. Tailer hauek ez dute «ghetto bezalako espazioak» izan nahi «non denak emakume «biktimak» diren»

Laugarrenik, Besarkatuz-en kasuan, pandemiarengatik baldintzatuta, haien ahalduntze estrategiak moldatu egin behar izan dituzte. Komentatzen dute orain espazio irekietara, esaterako parkeetara, joateko joera handiagoa dutela. Gogoratu behar dugu espazioa ez dela neutroa, hau da, boterearekin lotura estua duela (Cevedio, 2003). Hori dela eta, parkeetako bilera horiek «espazio publikoaren ahalduntze gisa» ulertzen dituzte. Horrez gain, emakumeen beste ahalduntze estrategietako bat Arte Ederren Museoaren laguntzarekin burutzen duten tailer bat da, zeina «arlo kulturaletik arlo pertsonalera eta sorkuntza artistikora doan, eta erlaxatzeko tarte bat ere baduen.» Estrategia honi ere gehitu behar zaio otorduen partekatzea edo Besarkatuz-eko kideek dioten bezala: «elkarrekin egotea, irteerak egitea kultura- eta aisialdi-guneetara, aldarrikapen-data zehatzetan parte hartzea...» Honek guztiak emakumeen ahalduntze prozesuan laguntzen duela sinesten dute.

Ahalduntze estrategiak, ordea, gizarte zibilaz gain Administrazioak ere bideratzen ditu. Honen inguruan, Haize Berria-ko kideak goraipatu egiten du Administrazioaren eginkizuna genero-indarkeriaren biktimentzako estrategien garapenean. Justifikatzeko honako hau dio: «egunez egun ikusten ari gara gero eta hedapen handiagoa dagoela emakumeen eskubideen alde, berdintasunaren alde.» Kontrako jarrera azaltzen dute Argitan zein Besarkatuz-etik argudiatuz «administrazioek, gaur egun arte, gaiaren publizitate-alderdiari baino ez diote ekin». Marketing horren guztiaren atzean, Argitan zein Erain-eko kideek azaltzen dute errealitate oso ezberdina dela, emakumeen ahalduntze estrategietan ardura gehiena gizarte zibilak izan duela.

Bestalde, estrategia horiek duten ikuspegi androzentrikoa (Matulic; Munté eta De Vicente, 2020) gainditzeari dagokionez, protagonisten artean adostasun zabala dugu. Haize Berria, Argitan eta Besarkatuz-en arabera, nolabaiteko espezializazio edo formazio feminista egon beharko litzateke Administrazioko arlo guztietan. Azkeneko bi hauen arabera 
esku-hartze sozial feminista beharrezkoa da: «mundu guztiak jakin behar du benetan zer gertatzen ari den beste aldean dagoen emakumearekin. Galdera bat egiterakoan, beste aldean dagoen pertsonak bizi duen egoera eta nola dagoen kontuan hartu behar da.» Haize Berria-ko kidearen arabera, antzematen da genero-indarkerian trebatuta dagoen langile batek artatzen zaituenean, zeren genero-indarkeriarekin lotutako aferak ezin ditu edozein abokatuk, psikologok edo hezitzaileak eraman. Halaber hurrengoa gehitzen du: «terapia psikologikoa egiten duten taldeen barruan, beti egon beharko litzateke psikologoekin batera genero indarkeria bizi eta gainditu duen emakume bat.» Haren ustetan, emakumeen ahalduntzerako oso baliagarria da egoera berbera sufritu eta gainditu duen beste batekin hitz egitea.

Erain-eko langilearen kasuan, enfasia jarri du Administrazioak guztizko prisma eraldaketa bat burutu behar duela. Alde batetik, Administrazio Publikoak bideratutako estrategiek emakumeei agentzia zein autonomia kentzen diela pentsatzen du. Bestetik, ikuspegi komunitarioa aplikatzea garrantzitsua dela dio: «Emakumeek biolentzia jasaten duten komunitateetan esku hartze komunitarioak egin behar dira haien ardura ere badelako. Ikuspegia ez da bakarrik emakume "koitadu” honetan jarri behar, zeren azkenean berbiktimazio prozesu bat gertatzen da.» Lanketa komunitario horien garrantzia azpimarratzen du biolentzia nondik datorren aztertzeaz gain biolentziaren gaineko tabu horrekin amaitzeko intentzioarekin.

\section{ONDORIOAK}

Lehenik eta behin, posizio ezberdinak dauden arren, protagonistek, nagusiki, iritzi kritikoa azaldu dute Administrazioaren bidez genero indarkeria dela-eta bizitegi bazterkeria pairatzen duten emakumeei eskaintzen zaizkien baliabideen inguruan. Kritikotasun horretatik interesgarria da nabarmentzea baliabide horiek emakumeen berbiktimizazioa eragiten dutela; baliabide estandarrak direla eta ez dagoela pertsonalizatuak izateko edo bakoitzaren beharretara moldatzeko aukerarik. Beraz, orokorrean, aipatzen da eskaintzen diren baliabideak ez dituztela emakume horien beharrak asetzen. Hala ere, iritzi hau ez dute guztiek partekatzen, protagonistetako batek eskaintzen diren baliabideak nahikoak direla kontsideratzeaz gain Administrazio Publikoaren papera goraipatzen du.

Bigarrenik, orokorrean aipatu da pandemiari aurre egiteko aplikatu diren neurriek (etxeko itxialdia, etxeratzeko agindua edo deseskalatzeak) negatiboki eragin dutela etxebizitza ez-seguruetan bizi diren emakumeen bizitegi egoeretan. Salatu dute halako neurriak aplikatzerakoan, beste behin, ez direla kontuan hartu etxebizitzaren alorrean jasaten diren indarkeria egoera horiek. Ikerketaren atal honi dagokionez, etxebizitzaren eraikuntza mitifikatua kategoria analitiko gisa interesgarria izan da, etxebizitza espazio segurutzat zalantzan jartzeko baliagarria izanik. 
Hirugarrenik, eta aipatu berri ditugun neurriekin lotuta, orokorrean aipatu da SARS-CoV-2 koronabirus pandemiak etxebizitza ez seguruetan bizi diren emakumeen genero indarkeria larriagotu duela. Kasu gehienetan salatu dute emakumeek itxialdian indarkeria jasateko aukera handiagoa izan dutela. Horrez gain, indarkeria egoera horretan aldaketak garatu direla ere esan daiteke erasotzaileek emakumeekiko zuten kontrola asko areagotu delako. Hala ere, indarkeriaren mekanismo psikologiko horiez gain, emakumeak indarkeria fisiko eta sexualak jasaten jarraitu dute.Protagonistetako baten arabera joera hau ezin da orokortu etxebizitza guztietara, batzuetan indarkeria egoera horiek baretu egin baitira kanpoko presiorik ez egotearen ondorioz. Ikuspegi hau interesgarria iruditu zait zeren erasotzailean arreta jartzen du eta saiatzen da ulertzen zerk eragin dion eraso hura egitera.

Laugarrenik, azkeneko helburuari dagokionez, genero indarkeriaren ondorioz etxebizitza ez seguruan bizi diren emakumeen ahalduntze estrategien inguruan, posizio ezberdinak aurkitu ditut. Bi elkarteko protagonistek aipatzen dute estrategia horien ardura gizarte zibilak hartu duela Administrazio Publikoa publizitatea egitera dedikatzen zen bitartean. Beste elkarteetako kide batek Administrazio Publikoaren papera oso positiboa dela aipatzen du eta, azkeneko kideak komentatzen du ikuspegi komunitarioa aplikatu beharra dagoela. Beraz, esan daiteke ahalduntzerako estrategien funtzionamenduari dagokionez iritzi ezberdinak aurkitu ditudala eta horiek harremanetan jartzen saiatu naiz.

\section{ERREFERENTZIA BIBLIOGRAFIKOAK}

Agulles, J.M.(2019). Las personas sin hogar y la exclusión residencial ¿hacia un cambio de paradigma?. Cuadernos de Trabajo Social (On-line), 32, (2), 265-275.

Balasch, M. eta Montenegro, M. (2003). Una propuesta metodológica desde la epistemología de los conocimiento situados: las producciones narrativas. Encuentros en Psicología Social, 1, 44-48.

Barrère, M.A. (2008). Género, discriminación y violencia contra las mujeres. In Laurenzo, P; Maqueda, M. L. eta Rubio, A. (koord.), Género, violencia y derecho (27-45). Valentzia: Tirant lo Blanch.

Bizitegi (2019). Estudio sobre la realidad de las mujeres en situación de exclusión residencial. Gasteiz: Departamento de Empleo y Políticas Sociales, Eusko Jaurlaritza-Gobierno Vasco.

Cevedio, M. (2003). Arquitectura y género: espacio público, espacio privado. Bartzelona: Icaria.

Col•lectiu Punt 6 (2019). Urbanismo feminista. Por una transformación radical de los espacios de vida. Bartzelona: Virus. 
Cortés, L. (1997). Hablando sobre la exclusión residencial. Madril: Cáritas.

Ehrenreich, B. eta English, D. (2010). Por tu propio bien. Madril: Capitán Swing.

FEANTSA (2007). Homelessness and Domestic Violence, eskuragarri hemen: https:// www.feantsa.org/en/feantsa-position/2007/01/03/feantsa-position-homelessnessand-domestic-violence?bcParent=27 [Kontsulta eguna: 2021/02/11]

FEANTSA (2015). The links between violence against women and homelessness, eskuragarri hemen: https://www.feantsa.org/en/feantsa-position/2015/07/03/feantsa-position-thelinks-between-violence-against-women-and-homelessness?bcParent=27 [Kontsulta eguna:2021/02/11]

FEANTSA (2017). ETHOS - European Typology on Homelessness and Housing Exclusion,eskuragarri hemen: https://www.feantsa.org/en/toolkit/2005/04/01/ethostypology-onhomelessness-and-housing-exclusion?bcParent=27 [Kontsulta eguna: 2021/02/11]

FEANTSA (2019). Women experiencing violence and homelessness: interlinked and unaddressed gender specific needs, eskuragarri hemen: https://www.feantsa.org/en/feantsaposition/2019/11/25/feantsa-background-paper-on-womens-homelessness-and-gender-based-violence?bcParent=27 [Kontsulta eguna: 2021/02/11]

Fundación Atenea (2018). Mujeres y exclusión residencial. Más allá del sinhogarismo. Madril: Departamento de Innovación y Conocimiento.

Gandarias, I. eta Gartzia, N. (2015). Producciones narrativas: una propuesta metodológica para la investigación feminista. In Mendia, I. eta Biblia, B. (koord.), Otras formas de (re)conocer. Reflexiones, herramientas y aplicaciones desde la investigación feminista (97-110). Euskal Herria: EHU/UPV.

Haraway, D. (1995). Capítulo 7: Conocimientos situados: la cuestión científica en el feminismo y el privilegio de la perspectiva parcial. Ciencia, cyborgs y mujeres. La invención de la naturaleza. Madril: Cátedra.

Hawkesworth, M. (2012). Truth and Truths in Feminist Knowledge Production. In Hesse-Biber, S.N. (ed.), Handbook of feminist research: theory and praxis (92-118). Londres: SAGE.

Hernández Pedreño, M. (2013). Capítulo 4: Exclusión residencial. In Hernández Pedreño, M. (koord.), Vivienda y exclusión residencial (109-134). Murtzia: Murtziako Unibertsitatea. 
John, N; E. Casey, S; Carino, G. eta McGovern, T. (2020). Lessons Never Learned: Crisis and gender-based violence. Developing World Bioethics (On-line), 20 (2), 65-68. https:// doi-org.bucm.idm.oclc.org/10.1111/dewb.12261

Kofman, Y. B. eta Garfin, D.R. (2020). Home is not always a haven: the domestic violence crisis amid the COVID-19 pandemic. Psychological Trauma: Theory, Research, Practice and Policy (On-line), 12 (1), 199-201.

Magro Servet, V. (2019). Violencia machista. Madril: Francis Lefevbre.

Matulic, M.V; Munté, A. eta De Vicente, I. (2020). Sinhogarismo femenino: una aproximación a la intersección entre género, edad y procesos migratorios. Research on Ageing and Social Policy (RASP), (On-line) 8 (1), 57-85.

Mesa, S. (2019). Silencio administrativo. Madril: Anagrama

Miller, K.L. eta Du Mont, J. (2000). Countless abused women: homeless and inadequately housed. Canadian Women Studies (On-line), 20 (3), 115-122, eskuragarri hemen: https://www-proquest- com.bucm.idm.oclc.org/docview/217461866/abstract/A7CCEC B528724858PQ/1?accountid=14514 [Kontsulta eguna: 2021/02/11]

Munduko Osasun Erakundea (2020). Gender and COVID-19: Advocacy brief. DOI:10.2307/ resrep28109

Osborne, R. (2009). Apuntes sobre violencia de género. Bartzelona: Edicions bellaterra

Osuji, J. eta Hirst, S. (2015). History of abuse and the experience of homelessness: a framework for assisting women overcome housing instability. Housing, Care and Support (On-line), 18 (3/4), 89-100.

Paglione, G. (2006). Domestic Violence and Housing Rights: A Reinterpretation of the Right to Housing. Human Rights Quarterly, 28 (1), 120-147, eskuragarri hemen: http:// www.jstor.org/stable/20072726 [Kontsulta eguna: 2021/02/17]

Pisarello, G. (2003). Vivienda para todos: un derecho en (de) construcción: el derecho a una vivienda digna y adecuada como derecho exigible. Bartzelona: Icaria.

Pujol, J. eta Montenegro, M. (2013): Producciones narrativas: una propuesta teórico-práctica para la investigación narrativa. In Paulín, H. eta Rodigou, M. (ed.), Coloquios de investigación cualitativa: desafíos en la investigación como relación social (15-42) Kordoba: Socialex. 
Sales, A. eta Guijarro, L. (2017). Dones sense llar: la invisibilització de l'exclusió residencial femenina. Barcelona Societat (On-line), 21, 99-108, eskuragarri hemen: https:// ajuntament.barcelona.cat/dretssocials/es/barcelona-societat-num-21-es [Kontsulta eguna:2021/02/11]

Savage, M. (2016). Gendering Women’s Homelessness. Irish Journal of Applied Social Studies (On-line) 16 (2).

Tacoronte, María José (2013). Reflexiones sobre la Tecnociencia desde una epistemología feminista. Acercamiento al pensamiento de D.J. Haraway. Cuestiones de género: de la igualdad y la diferencia, (8), 107-28.

Vicente, T; Rubio, E. eta Martínez, J. (2013). Capítulo 1: El derecho a la vivienda. In Hernández Pedreño, M. (koord.) Vivienda y exclusión residencial (23-48). Murtzia: Murtziako Unibertsitatea. 